Article

\title{
Expertise and Power: Agencies Operating in Complex Environments
}

\author{
Anthony R. Zito \\ School of Geography, Politics and Sociology, Newcastle University, Newcastle upon Tyne, NE1 7RU, UK; \\ E-Mail: anthony.zito@ncl.ac.uk; Tel.: +44-1912087554; Fax: +44-1912085069
}

Submitted: 2 June 2014 | In Revised Form: 14 February 2015 | Accepted: 19 February 2015 |

Published: 31 March 2015

\begin{abstract}
This contribution investigates the strategies that environmental agencies develop to enhance their policy autonomy, in order to fulfil their organisational missions for protecting the environment. This article asks whether there are particular strategic moves that an agency can make to augment this policy autonomy in the face of the principals. Critiquing principal agent theory, it investigates the evolution of three environmental agencies (the European Environment Agency, the England and Wales Environment Agency and the United States Environmental Protection Agency), focusing on the case study of climate change. The contribution examines how the agencies influence environmental policy on domestic, regional and global levels, with a special focus on the principals that constrain agency autonomy. A greater focus on different multi-level contexts, which the three agencies face, may create other possible dynamics and opportunities for agency strategies. Agencies can use particular knowledge, network and alliance building to strengthen their policy/political positions.
\end{abstract}

\section{Keywords}

climate change; environment agency; European Union; governance; learning; principal agent

\section{Issue}

This article is part of the special issue "The Role of Expert Knowledge in EU Executive Institutions", edited by Professor Åse Gornitzka (University of Oslo, Norway) and Dr. Cathrine Holst (University of Oslo, Norway).

(C) 2015 by the author; licensee Cogitatio (Lisbon, Portugal). This article is licensed under a Creative Commons Attribution 4.0 International License (CC BY).

\section{Introduction}

This contribution has a twofold analytical purpose. First, it studies environment agencies as prototypical public organisations wielding policy expertise and struggling with some of the most critical public policy questions affecting human well-being. Part of the governance challenge facing such agencies is the blurring of the line between the expertise needed to govern a policy problem and the political knowledge needed to govern most effectively. This governance difficulty is heightened by the multi-level nature of the political actors involved and the increasing presence of "wicked" problems (policy problems resisting resolution due to issue uncertainty and complexity). Problem-solving expertise is not the only knowledge that agencies must nurture: how agencies handle multiple masters mat- ters. This contribution emphasises that a necessarily important part of this governance effort involves developing strategies that engage the agency's principals and constituencies.

Secondly, exploring these policy-making aspects suggests the need to conceptually broaden the principalagent (PA) framework. The article examines the role that agent strategies can have in influencing the PA dynamic, and which strategic moves may succeed in providing the agency the policy scope to fulfil its core tasks. Hawkins and Jacoby (2006, p. 201) stress how PA theory has overlooked the importance of agent strategies in the policies that ensue. This raises the broader theoretical question largely absent from traditional PA approaches, namely assessing the importance of learning.

To achieve these objectives, we ask the following research question: are there particular strategic moves 
that an agency can make to enhance its policy autonomy with respect to the principals? The article explores the ability of agencies to learn strategies for engaging with both the principals and the other constituencies (those elements of society that are regulated and/or benefit from agency efforts). This article makes a focused comparison of the multi-level dynamics within the European Union (EU) and the United States (US) in the area of environmental policy, focusing particularly on climate change (CC). It investigates the policy efforts of the EU agency, the European Environment Agency (EEA) and the United States Environmental Protection Agency (USEPA). However, given the importance of domestic agencies in implementing EU law and governance (part of a "double delegation" where regulatory powers have been delegated both to the EU institutions and national agencies) we need to understand the transposition of EU law at the domestic level and its own PA dynamics (Coen \& Thatcher, 2008; Trondal, 2011, p. 58). The study adds the Environment Agency for England and Wales (EA) to the methodological approach discussed next.

\subsection{Methods and Outline}

In 2007, the Leverhulme Foundation funded a one year qualitative study enabling this researcher to examine three environmental agencies and the challenges that they face in the new millennium. The USEPA and the EEA were selected on the most different principle with respect to the question of policy scope (i.e., the power and authority to implement environmental law) within a multi-level context. Although both agencies operate in a multi-level dynamic, the USEPA has a substantially greater budgetary and regulatory scope over the US state-level agencies; in contrast, the EEA is an information-focused agency that relies on networks of national institutions and agencies to perform its policy role and has limited policy/budgetary scope over them. If we saw these two agencies following a similar strategy towards their principals in order to enhance policy control, this suggests a broader phenomenon is being observed. However, given the importance of understanding how member state agencies operate in the multi-level EU context, I drilled down further, adding the EA as an illustration. Given the ability to only look at one member state country, the EA was selected as the largest member state agency with considerable policy and information gathering responsibilities, operating within a member state government that originally took a very limiting perspective towards the EEA.

The initial study revealed that changes in executive government and legislatures mattered in shaping agency policy autonomy; to understand this time dimension, the author has continued the study into 2014. The research has involved examining the engagement with other organisations within the system and the instruments (policy tools) selected to implement environmental legislation. This has involved looking at academic literature, primary documents, (including annual reports, external assessments, and policy proposals), and conversations with expert academics. To get a detailed sense of the motivations and the degree to which implicit/explicit strategies existed, this researcher has utilised open-ended questionnaires to interview 78 organisational actors experienced in environmental policy-making, both within the particular agency and outside it. The interviews include three senior and four mid-level EEA officers, three consultants involved in EEA activities, three EEA Management Board members representing EU supranational institutions, four senior EA officials, five mid-level EA officials, three policy officers in the Department of Energy and Climate Change (DECC) and the Department of Environment, Food and Rural Affairs (DEFRA), three senior EPA political appointees, ten senior EPA permanent administrators, 27 EPA Headquarters policy officers, 8 USEPA Region policy officers, 8 policy officers in other departments (e.g., Office of Management and Budget and the Small Business Administration), four policy officers representing regulated groups and two Environment Canada officials.

In terms of data gathering, the investigation has focused on the evolution of the three agencies' effort to shape policy broadly and to engage with their respective principals. However, to more closely understand the organisational level mechanics (of building policy efforts, strategies and instruments), this article drills down further by selecting a specific policy problem, climate change. This allows closer isolation of the micro differences in policy preferences, and in information, between the principal and agent. In terms of the analytical propositions the next section examines, climate change is a testing case for the theoretical argument because of (a) its high political salience, (b) the degree of policy uncertainty and complexity inherent in the problem and (c) a wide range of actors perceiving a stake and being willing to contest this policy area. Because climate change policy encompasses so many environmental and non-environmental policy dimensions that are pursued within and outside the respective environment agencies, the project has focused on water policy issues and the most salient CC dockets (in terms of political attention) for each agency.

The next section formulates a number of theoretical propositions based on PA theory as well as two literatures that suggest critical changes: namely historical institutionalism and learning. The following section explores each agency's development, focusing on how the agencies have evolved in their relationship with their principals to achieve policy objectives. The article then examines the degree of policy autonomy found in the individual agency's CC policy efforts. 


\section{Theoretical Overview}

\subsection{Principal-Agent Approaches}

The foundational PA literature focused on the core relationships between bureaucratic organisations (the agents) and the principals, the political authorities. PA theorists conceptualised politicians as principals who anticipate the potential for bureaucratic manipulation (given the bureaucracy's superior expertise) and assert their long-term control over the agent (McCubbins, Noll, \& Weingast, 1987). The traditional PA approach assumes that bureaucrats have personal preferences that conflict with the principals' concerns, and the delegation of authority gives bureaucrats/agents information advantages -i.e., expertise (McCubbins et al., 1987, pp. 246-247). To avoid prohibitively costly monitoring and sanctioning costs, the principals build mechanisms that control the bureaucratic process, but do not require specifying or even knowing the detailed policy outcomes that bureaucrats pursue (Calvert, McCubbins, \& Weingast, 1989, pp. 598-599). This can involve: selection or screening of the agent, embedding positive incentives, monitoring procedures and sanctioning (Reichert \& Jungblut, 2007). This article's null hypothesis is the PA thesis: the policy actions that agencies pursue fall within the policy autonomy and discretion delegated by the principals (ConceiçãoHeldt, 2013; see Table 1 for the summary list). Policy autonomy is the actual (as opposed to the merely formal/legal) degree of policy-making competency an agency enjoys in relation to its "parent" ministry or government (Bach, Niklasson, \& Painter, 2012, p. 185).

In the PA perspective, the tension arises as the asymmetric balance of information between the principal and the agent, involving incompletely specified mandate or weak oversight mechanisms, creates the potential for agency slack (the ability to act independently and to exceed the delegated authority granted by the principals) (Hawkins, Lake, Nielson, \& Tierney, 2006). Thus, the traditional PA approach posits certain conditions where agencies may exert policy autonomy that is contrary to the principal's intentions. This agency slack occurs in conditions where the agency interests and consequent actions conflict with the principal (shirking) or where the structure of delegation gives incentives for the agency to take a different position (slippage) (Conceição-Heldt, 2013).

One of the most likely opportunities for agency slippage occurs when (a) the principle is a collective entity that must generate consensus to act and is divided; or (b) there are multiple principals (Thatcher \& StoneSweet, 2002). Not only can the agent play off the multiple actors (when they are unable to agree a common interest or agree to sanction the agent), the agency will be alert to the principals' decisional process, i.e., whether the principals require unanimity versus some form of majority vote to alter agency behaviour. These multiple actors may also have authority over different aspects of the principal's relationship. Koop (2011) finds that an increased number of principals involved in setting the agency's terms leads to greater problems of achieving compromise, a higher tendency for less detailed legislation and more opportunities for discretion.

Part of this slippage dynamic reflects a wider range of public and societal actors involved in governing. Governance networks, in which a mixture of state actors (which may include both the principals and multiple agents working on the same policy problem) and societal actors, have an increasing role (Coen \& Thatcher, 2008). Héritier and Lehmkuhl (2008, p. 15) push this argument further by stressing the possibility that actors can be both principals and agents simultaneously, creating more complex dynamics.

A second set of conditions that complicate the PA perspective are the characteristics inherent in the policy that the agency confronts. First, there is the question of how salient (the degree of importance given an issue by policy makers) the policy is that the agency is acting upon; the more politically salient the policy, the more likely principals will invest in monitoring and steering (Koop, 2011). Second, agency policy autonomy may depend on the stage that the policy is at: the acts of agenda setting, policy formulation, policy decision, policy implementation and policy monitoring may attract varying degrees of principal attention (Bach et al., 2012).

\subsection{Institutional Strategies and Learning}

The elaborations offered above do not challenge the essential PA dynamics. Some critics argue for the importance of other dynamics that move beyond PA assumptions. Thatcher and Stone Sweet (2002) raise the historical institutionalist argument that PA assumptions become problematic over time as preferences of both the principals and agents can change and complex interactions feed back into this process. Coen and Thatcher (2008, pp. 53-54) argue that the PA approach too easily ignores how, over time, the post-delegation behaviour may alter the original delegation, "driven by endogenous factors such as learning or the development of expertise, or exogenous factors such as technological and economic developments or external coercion". Exogenous technological factors may involve the creation of information technology that enhances policy scope but cannot be anticipated by the principals in earlier legislation. While accepting the potential importance of exogenous factors in enhancing policy autonomy, this contribution focuses on the endogenous dynamics, explored next.

Hawkins and Jacoby (2006, p. 199) note that the PA focus on the principal's control mechanisms has led to 
the consequent neglect of the strategies that agents pursue in between the act of delegation and the actual policy outcomes. They posit that agents are able to increase their autonomy by three strategies outlined below. First, agents can embrace strategies that involve a certain level of deception or mis-direction. One plausible way is "dualism", i.e., creating a covert buffer between the agent and the principal by differentiating between core tasks that the agency wishes to fulfil and the actual tasks that please the principals and other third party constituents (Hawkins \& Jacoby, 2006, pp. 210-211). Particularly when facing multiple demands and a growing number of principals and other interested parties, agencies may have the ability to loosely couple sufficient activity to please certain principals whilst operating to achieve objectives not pleasing to these particular principals.

Less covert is the second strategy. Agents can choose to reinterpret the delegation rules by (a) gradually but visibly reinterpreting the rules in a way that gives the principal time to adapt and not be goaded into overturning the reinterpretation; (b) reinterpreting the rules in a way that splits the collective/multiple principles; (c) adhering to the principal's goals but modifying/innovating the implementation in a manner that establishes future precedents; and (d) developing informal practices that the agent asks to be formalised (Hawkins \& Jacoby, 2006, pp. 206-207, 212).

These strategic possibilities of reinterpretation suggest a larger reality: agencies may find the scope to alter the substantive preferences of the principals and other important stakeholders over time. This does not constitute shirking as the agency acts to transform the policy dynamics and the principals' preferences. The difference is that shirking is the explicit effort to circumvent the will of the principal as expressed in the PA control mechanisms; this has democratic implications given the circumvention of democratic representatives. The preference transformation involves the persuasion of the principal on a voluntary basis to accept new understandings of policy. Tallberg (2002, pp. 37-39) argues that there is an inherent element of learning in any principal-agent relationship. PA relationships are not "one-shot affairs": both principals and agents seek to integrate previous experience with future behaviour. This article goes further by postulating that agencies can adjust and have the ability to make principals adjust over time through a learning process.

Hawkins and Jacoby suggest a third agency strategy involving third parties. PA theory acknowledges this possibility, with these groups acting as monitors for the principal that trigger alarms about agency shirking. However, the dynamic also works in reverse. As autonomous agents that are supposed to be open to policy stakeholders, it is difficult to stop agents from expanding the range of actors that they engage. Such monitor- ing stakeholders may share or be persuaded to adopt the agency outlook, building coalitions to support the agent's policy efforts (Hawkins \& Jacoby, 2006, pp. 208-209). Agencies have incentives to ally themselves with principals and other interested parties who share their goals and policy outlook; sharing ideas and information/expertise becomes a means of cementing this linkage to supporting coalitions (Waterman, Rouse, \& Wright, 2004, pp. 37-42).

Carpenter offers a historical institutionalist analysis of bureaucratic autonomy that reinforces Hawkins and Jacoby's strategies, particularly reinterpretation/innovation and building linkages/coalitions with third party actors. Bureaucratic autonomy involves agencies undertaking "sustained patterns of action" over time that accord with their own policy preferences. Carpenter suggests that bureaucracies need stable legitimacy in order to operate autonomously. Agencies attain this condition by developing a reputation and expertise in policy innovation (that becomes recognised by principals and wider society) and by establishing societal links more widely (Carpenter, 2001, pp. 14-18). Genuine policy autonomy exists when agencies can make the decisive first moves towards a new policy, establishing the most popular alternative (the policy innovation), which become too costly for politicians and organised interests to ignore or dismiss.

Agencies operating with policy autonomy may exert a process of bureaucratic entrepreneurship (Carpenter, 2001, pp. 30-31): the agency leadership, harnessing the agency's expertise, introduces innovations to existing programmes and/or new programmes while gradually convincing the diverse political actors and coalitions to value the new innovation and the agencies themselves (both are essential acts of policy entrepreneurship). Agency actors sustain this preference shift by using recognised policy legitimacy, by building superior ties to the public and/or media, or by establishing reputations for impartiality or the pursuit of public good. For example, if agencies can build in advance compromises on policy elements with the various important stakeholders affected by the policy, then they can reduce the incentives of these societal stakeholders to raise objections and galvanise principals (Lee, 2012).

Waterman, Rouse and Wright (2004, pp. 37-42) conclude that information, learning and coalition building are core dynamics that transform the bureaucracyprincipal relationship: both sets of actors are learning over time about policy, politics and their own organisations. Bennett and Howlett (1992, pp. 278-288) suggest several relevant distinctions for different types of learning. "Government learning" focuses on understanding the administrative processes with the aim of organisational change; this maps onto agencies learning how to divide or persuade principals by building coalitions with certain principals and other societal actors. "Lesson drawing" focuses on how programmes 
change via actors learning about new instruments and tools; such learning enables agencies to reinterpret their roles in a way that principals eventually learn to accept. "Social learning" encompasses the learning process where new world views are adopted, leading to radical policy paradigms shifts. This encompassed the rarer possibility that an agency will gain an understanding of public policy that transforms the policy role itself (Bennett \& Howlett, 1992).

Table 1 summarises the propositions offered in this section. Evidence for the first proposition suggests that normal PA delegation operates. Propositions Two to Five suggest conditions that can be encompassed within the PA approach. Proposition Three allows for a range of possibilities, including: the principal cannot generate a consensus within its constituent elements; multiple principals cannot agree a course of action; and the principals' outlook and priorities alters over time, due to changes in the executive and legislature. Proposition Five expresses the possibility that the principal and any supporting actors may focus more, for example, on the agency actions during the policy formulation and decision-making but less so in the implementation and monitoring phases. Proposition Six includes exogenous forces such as economic crises and environmental disasters that raise certain aspects that agencies wish to prioritise beyond what is established in the initial PA delegation.

Propositions Seven to Nine articulate the three strategies agencies can utilise to transform the nature of the PA relationship. It is possible that such strategies would be more likely to succeed if they are interacting together. Agencies actively push innovation and seek a wider actor coalition to embrace this knowledge and embed it into their own routines and behavioural norms. All three forms of learning may occur in this situation, but agency learning about the policy problem and its engagement with both the principals and the wider policy context is more likely to involve limited lesson drawing (e.g., incrementally improved understandings of the policy problem and new perspectives on instruments) and government learning that does not modify radically the organisational strategy and worldview.

My overarching hypothesis is that we should see similar strategies being adopted by the three agencies to enhance their policy autonomy in a complex multilevel context and that the agencies will be attracted to transformational strategies that reduce the potential for conflict with the principals. It is expected that more than one of the conditions in Table 1 may have to be in operation for the agency to gain this autonomy in a situation that does not result in a strong principal reaction. If the agency's operations in general, and in climate change specifically, are limited to the autonomy as outlined by the principal, the PA proposition holds.
Table 1: Propositions.

\begin{tabular}{ll}
\hline List of propositions & $\begin{array}{l}\text { Expectations concerning the } \\
\text { agency's policy autonomy }\end{array}$ \\
\hline
\end{tabular}

Null hypothesis

(1) The default PA proposition

Policy autonomy is stable, reflecting normal PA delegation.

Propositions where PA dynamics remain but are made more complicated

(2) Shirking

Policy autonomy increases for agency acting against principal's intentions.

(3) Slippage

Policy autonomy increases as agency exploits changes in the delegation or the lack of principal consensus due to:

(a) composite principals;

(b) multiple principals;

(c) external changes in the principals.

(4) Policy saliency

Policy autonomy increases to the degree that the policy issue garners less political attention.

(5) Policy stage

Policy autonomy increases at the policy stage that draws less attention from principals and stakeholders.

(6) Exogenous dynamics

Policy autonomy increases

due to external

circumstances.

\section{Propositions that transform PA dynamics}

(7) Dualism

(8) Reinterpretation and learning

(9) Coalition-building
Policy autonomy increases due to agency deception and loose coupling of tasks.

Policy autonomy increases as agency engages in reinterpreting its mandate or transforming the understanding of its role.

Policy autonomy increases as agency learns to persuade principals and others to be sympathetic to agency's position. 


\section{Comparative Analysis}

Taking each agency in turn, this section first focuses on changes in the agency's policy autonomy, and provides an overview of the changes in the balance between the agency and the principals. Then each agency study drills down to investigate how agency policy autonomy has manifested itself in the CC case. Following the focused comparison approach, the USEPA is examined, followed by the EEA, with the illustration of a member state agency, the EA. Table 2 introduces some of the key agency differences (in terms of the range of principals, the scope of the tasks and the range of steering mechanisms that principals possess) that each agency overview discusses.

\subsection{The USEPA}

\subsubsection{The Evolving PA Relationship}

The 1970 order creating the USEPA enshrined a very important distinction from the other two agencies: the Presidential administration's selection of political appointees to head both the agency and its key offices. This is a clear PA control mechanism; these appointees are agents with a more direct link and association to the principal. However, the impact and control of these officials varied widely depending on the individual. Some of the more effective USEPA Administrators, particularly Ruckleshaus, developed their own independent political base and prestige in office, but the political appointees mostly bring whatever political leverage accumulated in their past political/policy lives-e.g., prominent state governors (Interviews, USEPA officials, 2007-2008).

Also present from the start was a separate principal: the US Congress. This body, particularly when its houses are controlled by the US party opposing the President, can exert quite different pressures on the USEPA. Not only must the US Senate approve the EPA appointees, the US Congress must create the environmental protection legislation, which the EPA implements, and decide the budgetary amount for the federal government, including the EPA and its programmes (Lazarus, 2004). Congress can also use appropriations bills to forbid agencies from spending the money to perform particular policy acts (MacDonald, 2013). Although Congressional Committees have the ability to investigate through hearings and other mechanisms, the general preference is to rely on interest groups and citizens to raise problems (Carrigan \& Coglianese, 2011). After the USEPA's initial founding, the Democrat-controlled US Congress spent the 1970s distrusting the Republican White House administration and its agents, producing a wide range of statutes imposing stringent deadlines and limiting the EPA's discretion. Congress also inserted various judicial review provisions that allowed, and indeed encouraged, both the regulated and public interest organisations such as the environmental non-governmental organisations (ENGOs) to pursue litigation (Lazarus, 2004, pp. 79-81).

Table 2: Agency characteristics.

\begin{tabular}{ll}
\hline Agency Name & USEPA \\
\hline Key Principals & Presidential Administration \\
& and Executive; US Congress.
\end{tabular}

EEA

EA

EU Commission, with

budget within DG

Environment; European

Parliament (EP); EU Council

of Ministers; member states.

Key Tasks

Implements US law by writing regulations and national standards; enforcing regulations; dispersal of US budget to states and other actors.

Critical mechanisms to limit agency policy autonomy after the delegation
Political appointees leading key EPA segments; formulating rules under executive scrutiny and processes; Congressional approval of appointees, oversight and budget approval; consultation and engagement by societal stakeholders (may involve litigation).
Gathering information to support policy implementation; coordinating member state networks.

Appointment of the chair by the Management Board; the Management Board interactions; special reviews of activities; reporting especially to the Commission and other EU institutions.
The UK executive with respect to England and Wales, with specific Ministerial oversight in DEFRA and DECC; House of Commons and Welsh Assembly; EU Commission.

Implement national and EU legislation, via issue of permits; acting as the competent authority responsible for implementing legislation.

Agency reviews; government budgets; restructuring; reporting to UK and EU governing processes; engagement with societal actors who provide information to both the UK and EU governance structures. 
One of the key alterations in the PA dynamics occurred with the Reagan Administration's arrival. The administration sought to subordinate the agency to a number of administrative measures; it created a number of Cabinet Councils to consider policy questions, marginalising the USEPA (Landy, Roberts, \& Thomas, 1994, pp. 248-250). The Reagan Administration also utilised an existing, centralising institution: the Office of Management and Budget (OMB). The White House issued an executive order requiring all proposed major rulemaking to be submitted to the OMB for review and enabling the $\mathrm{OMB}$ to examine all extant rules (Interviews, USEPA officials, 2007-2011; Carrigan \& Coglianese, 2011). The third control mechanism involved budgetary limits: the USEPA had to implement numerous 1970s laws, but the White House, waging a substantial battle with the Democrat-controlled Congress, substantially contracted the EPA budget between 1980 and 1983 (Landy et al., 1994, pp. 248-250).

Subsequent presidential administrations used these mechanisms-although for varying objectives. For example, the Bush II Administration budget cuts (without directly challenging national law and the environmental coalitions) compelled the USEPA to re-prioritise what they saw as vital activities and abandon less essential items (Interviews, USEPA officials, 2007-2008).

\subsubsection{Climate Policy}

The USEPA CC policy starts with the 1989-1990 publication of two substantial climate documents arguing for stringent policy efforts (Landy et al., 1994, pp. 291295). The Bush Sr. Administration was unwilling to follow through with a substantial mitigation agenda, either at the national or international level; the Clinton era saw a more favourable CC approach. Given space constraints, this case study focuses on the Bush II and Obama Presidencies where diverging preferences between principals (the Executive and Congress) and the USEPA can be strongly documented.

For most of the Bush II Presidency, the USEPA's CC focus was relatively limited. In 2002, President Bush announced the plan to reduce greenhouse gas intensity by $18 \%$ over a decade (USEPA Interviews, 23-24/11/2009). The USEPA was encouraged to pursue some lesson drawing about CC instruments; this exploration centred on developing voluntary climate efforts, and exploring technological solutions in areas such as transport (Interviews, USEPA official, 9/11/2012, USEPA officials, 2324/11/2009). Accordingly, the USEPA joined the Department of Energy to implement the ENERGY STAR programme promoting energy-efficient products and processes (Interview former USEPA official, 19/11/13).

The PA constraint was reflected most significantly in the actions and outlook of the Headquarters Unit, based so near the White House. There was a clear recognition that a more interventionist USEPA program was not possible given the Bush Presidency's orientation. Numerous interviews suggest that a PA dynamic was at work where the preferences of the principal and agent differed: many lower level managers in the EPA Headquarters were simply "waiting" for a change of administration (Interviews, USEPA officials, 2007-2008, 2013). This early half of the Bush II era suggests that both the limited EPA efforts and the actual policy instrument innovation aligned with the general White House preferences (fitting with Proposition One).

However, this does not indicate all of the significant USEPA CC involvement. The lower (regional) USEPA layers have been involved with a number of state initiatives as well as carrying out their own limited activities. Here the states, as important policy stakeholders that receive USEPA rules and money, have provided strong governance leadership. This dynamic changed further as the state actors collided with the Bush Administration. In 2003, nine New England and MidAtlantic governors started negotiating a regional tradable permit scheme for emissions for power plants. This led to the 2005 memorandum of understanding (MOU) creating the Regional Greenhouse Gas Initiative (RGGI, 2009). Although a number of them had Republican governors, the state governments decided to tackle this issue in the perceived absence of Presidential leadership. This effort developed a transnational dimension as the same governors held discussions, again supported by the regional EPA officials, with the Canadian provincial premiers prioritising climate change.

This left the USEPA Region 1 (covering the New England States) and Region 3 (Mid-Atlantic States) Headquarters with a balancing act. The USEPA reality is that the more regional agency elements must work closely with the state governments and environmental protection agencies to ensure implementation of the national laws and regulatory targets as well as adhere to the federal principals' preferences (Interviews, state representatives, 2012). In this context, the Region 1 leadership consulted closely with the governors, giving policy advice. This effort maintained low visibility, without involving a specific budget; resources within the offices were shifted from the traditional handling of issues to this CC question. This Regional EPA effort constitutes coalition building (Proposition Nine) around the climate change objective, but with the states taking the active policy leadership. These two Regional offices were able to carve out their own small niches to tackle climate change even during the Bush II era. As the Bush Il Administration had to be careful about issues of state's rights, particularly for states with Republican leadership this suggests some slippage for the principal (Proposition Three), which gave the USEPA more room to act in conjunction with these states.

Further policy autonomy is seen in each Region's implementation of the Safe Water Drinking Act (SWDA) (Interviews, USEPA officials, 2008). To implement this 
legislation, the top managers of Region 1 actively incorporated CC issues, using the rationale that the potential CC impact on water systems raised questions for the drinking water objectives. This thinking chimed with the national media office, the Office of Water. As the SWDA did not have CC as a primary policy focus, the Regional officers engaged in some reinterpretation of laws they were required to implement. Therefore Regional Office 1 shifted some resources to address this CC problem. The office turned the available tools dealing with the water issue to the linked CC area, such as the monitoring of the waste water industry's energy efficiency. A similar shifting of effort and purpose occurred in energy conservation efforts. These findings suggest that both slippage and dualism occurred, as certain Water objectives set by Congress gave the EPA greater scope to work on CC contrary to the wishes of the Executive. It also helped the Regional office that they were seeking to implement a piece of US legislation (Proposition 5), but reinterpretation was also involved. This supports Opp's (2011) findings that USEPA regions can possess a varying degree of discretion; this in turn influences how states and localities implement national legislation.

It is important not to overstate the impact of this USEPA policy autonomy. Much of the USEPA effort was done under the policy radar screen at the national level and at the margins. For the USEPA, the greater policy changes happened elsewhere. Congress developed several bills to directly tackle CC and distance itself from the White House. Of more immediate importance to the USEPA was the 2007 US Supreme Court ruling against the USEPA. Here a number of petitioners, joined by the state of Massachusetts, sought to see greenhouse gas emissions as pollutants that can be regulated under the extant US law (the Clean Air Act-CAA); the Court decided for the petitioners (Massachusetts et al. v. Environmental Protection Agency et al., 2007). The USEPA responded to this Supreme Court decision by empowering its Office of Air and Radiation to develop rules to tackle greenhouse gasses through the CAA (USEPA, 2008; Interview, USEPA official, 2007). The Court ruling and the use of current regulations suggest the slippage dynamic; here a key PA monitoring device, legal action, forced a readjustment by the executive and the EPA, rather than an USEPA-led reinterpretation.

It is telling that the Bush Administration and the EPA Administrator Johnson managed to tone down the critical finding about CC endangerment in the EPA draft response to the ruling, (McGarity, 2013). In these circumstances, the EPA continued to develop several rules (including one that the OMB refused to upload and thus finalise the review process) and research to support the policy efforts (Heinzerling, 2012). The amount of effort the EPA staff spent on this suggests shirking, with the anticipation of future principal slippage.

With the arrival of the Obama administration and new political appointees, notable changes can be seen. In response to the 2007 Supreme Court Decision, the USEPA Administrator Jackson signed an action that the current and projected concentrations of the six key greenhouse gases be considered a threat to the "public health and welfare of current and future generations" (USEPA, 2009). This action acknowledged the CC threat, triggering mandatory action under the CAA. Obama signed the American Recovery and Reinvestment Act in 2009; it provided the USEPA, among other things, with $\$ 6$ billion to tackle energy efficiency and the ability of water systems to cope with CC (Recovery.gov, 2009).

In the wake of significant bipartisan opposition in Congress and the healthcare battle, the Obama Administration prioritised using the 2007 Court ruling to exploit extant regulations, particularly the CAA (Cappiello, 2009). Accordingly, the EPA proposed a Carbon Pollution Standard for New Power Plants that defines national limits on the carbon emissions for the first time (USEPA, 2012). The Rule continues to be developed in 2015; there are indications that it will incorporate the state-led tradable permit scheme to achieve its goals (Volcovici, 2014).

However, by 2012 the political tide had turned in the US Congress with a resurgence of the Republican right taking the US House of Representatives, symbolised by the House Committee on Oversight and Government Reform requiring the EPA Administrator Jackson to testify seven times in one month (McGarity, 2013). Although the USEPA pursues standards on cars and power plants (including work started during the Bush Administration), the EPA has delayed other tools given this principal and societal opposition (Heinzerling, 2012). The EPA Climate Change Division has sought to mitigate this opposition by pursuing the participation and views of various stakeholders while developing the Mandatory Reporting of Greenhouse Gases Rule. Cook and Rinfret (2013) find that this EPA (coalition-building) strategy is one the Agency is pursuing in other rule-making efforts.

The analysis above suggests that the EPA has not gained much policy autonomy concerning CC; much more significant has been the change in the principals' thinking, particularly the White House, and the clients, including state governments. The USEPA is more notable for its ability to maintain its expertise and general approach to the policy problem while waiting for the principal to change: the preferences of the executive under Obama and the agency converged more strongly (Interview, USEPA official, November 2013).

\subsection{The EEA}

\subsubsection{The Evolving PA Relationship}

The EU Regulation 1210/90 creating the EEA established both the PA dynamics and the opportunities to form broader relationships. The Regulation also con- 
tained notable ambiguities - particularly the EEA's relationship to the Commission and its role in formulating EU policy (Majone, 1997). The composition of the overseeing EEA Management Board included a range of principals (see Table 2), namely the EP, Commission and state representatives, who had haggled over the Agency's original role (Groenleer, 2009; Zito, 2009).

The compromise Regulation placed the EEA in a role of information and network co-ordination (Ladeur, 1996); it explicitly mandated the network system to utilise extant European structures and hence engage with national institutions (Commission, 1989). The EIONET network contained nine specialist European Topic Centres (ETC) and the National Focal Pointsnational institutions tasked with assisting the EEA work programme and the EIONET (EEA, n.d.). Regulation Article 14 specifically mandates EEA co-operation with other international organisations, giving the networking global scope (Council, 1990).

The EEA has harnessed its network agency mandate to engage both internal and external actors linked to the EU policy-making process. The EIONET system requires substantial networking with a range of state officials and civil society. The original Regulation offers possibilities for interpretation/re-interpretation to allow the EEA officials to expand its tasks, which involved certain policy implications (Interviews, two EEA officials, 2007; Groenleer, 2009). The Regulation's ambiguous language strongly suggests the importance of slippage, which was driven by a compromise between the key principals with differing priorities. Accordingly, the EEA officials used the Regulatory obligation to interact with non-EU countries and international bodies to showcase EEA expertise, experience and knowledge about networking and data collection (Interviews, two EEA officials, 2007).

Shifting to another PA dynamic, the original Regulation required that the Commission review the Agency's performance and make proposals concerning additional tasks to the Council (Council, 1999, p. 1). Several principals (e.g., the EP) viewed this provision as a mechanism for expanding EEA power (slippage). Simultaneously, the review could serve as the traditional PA monitoring tool to assess performance, potentially triggering constraints and sanctions. The review, started in 1997, could have produced widely varying results, depending on the principals' perceptions and actions.

The consequent revised Regulation 933/1999 offered nothing dramatic but included significant changes of nuance, allowing slippage. The Revised Article 2 reformulates the aims "to provide the Community and the Member States with the objective information necessary for framing and implementing sound and effective environmental policies" (Council, 1999, p. 2). This changed the interpretation of the EEA's role as moving from mere data collection to one involving an explicit policy function and expertise.
This revised Regulation pushed the Agency to engage in some governmental learning, via reforming its information systems and gaining a new focus on sectoral integration and prospective analysis (IEEP [Institute for European Environmental Policy] \& EIPA [European Institute for Public Administration], 2003, p. 26). The revised Regulation enshrined a PA monitoring process, requiring a further review of the agency's performance by the principals (Council, 1999, p. 2).

This second major review assessed positively the 1994-2000 EEA performance, affirming the need for the Agency and EIONET (IEEP \& EIPA, 2003, pp. 26-27). It argued that the Agency's work needed to fit more closely with the clients' (principal's) needs, but that it could not serve all users, nor all policy areas, given extremely limited resources. The review argued that the EEA's role needed to shift from providing stand alone products (such as reports) to providing services to the policy-making actors. This recommendation provided scope for agency task expansion in the area of policy (Ibid). The Review also triggered an explicit Council statement enshrining the EEA's independent role as serving the entire EU, granting some policy autonomy in conditions of slippage (Interview, Management Board, 2007; Council, 2003).

Another active PA mechanism is the EEA Management Board (MB). The MB must approve the EEA work programme and various organisational/staffing decisions; it acts as conduit of information and networking between the EEA and its principals. The PA dynamic has gradually evolved from 1990: e.g., the MB preferences becoming more diffuse after EU enlargement, allowing more opportunities for slippage.

The critical relationship with Commission DG for Environment (the DG has special control and is the location of the EEA budget) has significantly changed from 2000 and has added some dimensions of policy autonomy, compared to previous academic assessments (e.g., Hoornbeek, 2000). Before that, some Commission officials held that the EEA takes the DG's money and accordingly obligated to do its bidding (EEA actor interview, 2007; IEEP \& EIPA, 2003, pp. 62-63). The policy role has been core in the EEA evolution away from merely writing informational reports and maintaining databases. This Agency policy activity generated tension with DG Environment's view of the Commission as the chief agent governing environmental policy and also the EEA's chief client; the 1998 and 2000 budget demonstrated the DG resistance and desire to downgrade lower EEA priority tasks (IEEP \& EIPA, 2003, pp. 38-40, 61-62). Nevertheless, the EEA leadership grasped that the provision of environmental information is inherently ambiguous and not policy neutral: data gathering involves assessing how policy problems are perceived and how policies function (Interviews, 2 EEA officials 2007). This development suggests both policy slippage and reinterpretation/ 
governmental learning concerning the EEA's potential.

Although differences in opinion remain about the EEA role in policy implementation and effectiveness, the Commission and the EEA have developed a more collaborative relationship (IEEP \& EIPA, 2003, pp. 4243; Groenleer, 2009). The EEA fashioned a more sensitive approach to the DG and senior and middle management interactions (Interviews, 2 EEA officials, one MB official, 2007; IEEP \& EIPA, 2003, pp. 60-62). The Commission has accepted the policy reinterpretation, explicitly acknowledging the importance of EEA's role and a potential extension of EEA support activities "along the entire range of stages of the policy cycle" (Commission, 2003, p. 10; Interview, MB official, 2007).

The role of competing principals and slippage has shaped this evolution as the EEA created deeper ties (Proposition Nine) to the EP, the Council and likeminded member states (Busuioc \& Groenleer, 2012, p. 140; IEEP and EIPA, 2003, p. 42). The EEA has sought to be responsive to state wishes through the development of conferences and background notes (i.e., background policy expertise). Changes in EU policy processes and demands have boosted this expanding EEA policy role (IEEP \& EIPA, 2003, pp. 28-29). The Cardiff process and the Sixth Action Programme generated particular policy requests (by the principals) for specific Agency information.

The EP Environment Committee boosted the EEA scope. The Committee requested ad hoc reports and background material on Commission legislative proposals and on related member state activity. This data requirement, focusing on general policy aspects, differed from the more detailed information that the Commission wanted the EEA to prioritise (Groenleer, 2009 , p. 234). This request was partly a conscious EP effort to boost the EEA's scope to conduct a level of discrete, limited policy analysis and provide policy expertise; a MOU between the EEA and EP concretised this effort (Interview, MB official, 2007). Two initial policy contributions (assessing the effectiveness of packaging waste implementation and of the urban waste water treatment directives) concretised this effort (IEEP \& EIPA, 2003, p. 32; Interview, consultant, 2007). The consequent relatively stable principal-agent linkages suggest the EEA's ability, albeit in a limited fashion, to reinterpret its role to include policy. This supports Trondal's (2010, p. 164) assessment about the trajectory of EU agencies.

\subsubsection{Climate Policy}

The EEA's role in CC policy indicates limitations in the policy autonomy that the EEA has gained. On this issue, the EEA has remained focused on activities set out by the principals. For example, the EEA has used its data expertise to assist the other institutions in developing the Greenhouse Gas Monitoring Mechanism. The main
EEA emphasis has been to help monitor and assess the EU progress in achieving emissions targets (EEA, 2009, pp. 11, 19). The EEA issued a 2007 report, arguing for the need to adapt water resource policy and suggesting a range of tools to help (EEA, 2007).

The EEA also provides analysis for planning a European low-carbon economy and support information for the latest international climate negotiations. The lowcarbon economy analyses include the study of integrated mitigation and adaptation outlooks, as well as analysing future scenarios. Special attention is devoted to improving and maintaining information and indicators of the climate change impacts, looking at current trends as well as hindcasting and forecasting Europe's climate (EEA, 2009, p. 19). The EEA has the annual responsibility of reporting the inventory of EU climate change emissions to UN Framework Convention on Climate Change process (EEA, 2015). The EEA's CC efforts reflect the standard PA dynamic: providing data and a limited amount of policy analysis at the behest of the Commission, member states and the EP.

\subsection{The $E A$}

\subsubsection{The Evolving PA Relationship}

The 1996 creation of the EA involved a merger of various organisations; this triggered a period (1996-1998) of considerable staff adjustment, low staff morale and a lack of management consensus about the agency's tasks and processes (Interview, 3 EA officials, 2007; McMahon, 2006, pp. 156-157). An additional challenge was pleasing the array of principals (see Table 2); these included the UK government (with particular oversight from DEFRA but also DECC concerning CC responsibilities), but also the House of Commons, the Welsh Assembly and the EU Treaty obligations monitored and enforced particularly by the Commission.

Perhaps the most notable UK government intervention and imposition of will from 2002 to 2014 has been the considerable and seemingly perpetual organisational restructuring and personnel changes, which partly explains continuing staff tensions (Interviews, 3 EA officials, 2007; 22 June 2010). A major 2002-2007 restructuring occurred to ensure that the EA produced a consistent set of instructions and uniform policy decisions at the sub-national level (Interview, EA official, 14 March 2007; House of Commons Environment Committee, 2006, pp. 16-17).

The 2010 UK Coalition Government forced further significant organisational changes, and has been conducting reviews with potentially drastic consequences for the EA, not least a review assessing the value of UK's EU membership. At the sector level, the government eliminated 53 of 85 of DEFRA advisory bodies (e.g., the Expert Panel on Air Quality Standards) in the "bonfire of the quangoes" (Interview, DEFRA official, 11 October 
2011; ENDS Report, 2010). Although the EA survived the initial purge, the Government ordered a triennial review of UK ministries, and all associated "arm's length" agencies to examine the need for agencies to exist outside the ministries and/or as independent entities (DEFRA, 2012b). In June 2013 the review concluded that the EA should remain a separate body but also continue to enhance service delivery and efficiencies (DEFRA, 2013).

As of 2014, budget cuts have forced the largest organisational changes. The Coalition Government has particularly cut DEFRA (the ministry providing the major budget for the EA). By December 2012, the Agency had lost $20 \%$ of its budget and 2000 member of staff. The Government forced cuts in a key climate changerelated issue area, flooding, but the 2012 floods forced a partial reversal (Carrington, 2012; Interview, EA Official, 2010). In 2014, during the winter floods crisis, the EA announced that the objective to cut the work force from 11250 to 9700 was still planned after a consultation period (BBC News, 2014).

Besides changing the budgetary cuts and reviews, the Coalition government gave a very clear steer that the EA should not challenge Government policy and should have a more internal organisational focus. From 1996 to this point, the EA, although enforcement remained its primary role, had increasingly viewed its general UK policy role as being an environment champion and had worked to shape policy (Interviews, 6 EA staff, 2007, 2008, 2010). DEFRA specifically told the EA to "stop policymaking and lobbying activities" (ENDS Report, October 2010). The EA leadership responded explicitly, dropping policy stances and altering job titles (Interview, EA Official, 2010).

One of the efforts to adjust the EA relationship with the UK and EU principals has involved learning (balanced more towards lesson drawing than social learning) about policy. The Agency had decided to make an effort to modernise environmental regulation, even before the 1997 New Labour government made it a priority (Interview, EA official, 1 December 2010). This reflects EA recognition that regulatory management must maximise efficiency, given ongoing resource constraints (DEFRA, 2003, pp. 12-16; House of Commons Environment Committee, 2006, pp. 13-15). The 2010 Coalition Government pushed DEFRA and the EA to streamline environmental regulation further (DEFRA, 2012a). This culminated in the development of new civil sanctions powers sourced in the 2008 Regulatory Enforcement and Sanctions Act. Interviews suggest that both high level and mid-level EA officials took particular interest in the USEPA's wide range of potential sanctioning tools (e.g., fines and voluntary agreements to undertake remedial action to supplement regulation) (Interviews, EA, USEPA officials, 2007-2008). This EA reinterpretation and learning about policy tools does not constitute shirking or transformation as it matches the preferences of the UK governments in the last two decades.
The EA leadership has endeavoured to enhance its impact, through such innovations, at both the international and EU levels. The EA became a prime mover of the Networks of the Heads of Environmental Protection Agencies (Interview EEA actor, 2007). The EA has been also active in the Implementation and Enforcement of Environmental Law (IMPEL) and EEA networks, pushing ideas such as the better regulation agenda (Interview, EA officials, 2007).

Because the EA is a competent authority for implementing EU regulations, the UK ministries had to include the EA in discussing new EU measures. Over time, the EU Commission has learned to respect the EA's input in its own right (Interviews, Consultant \& EA officials, 2007).The Agency utilises an evidence-based approach to its argumentation that the Commission finds useful (Interview, EA officials, 2007). Important EU policy examples include: the general structure and provisions of the Water Framework Directive and the use of risk-based calculations in the Contaminated Land Directive (Interview, EA official, 2007).

Nevertheless, DEFRA, as a core principal that is the voice of the UK ministerial government in the EU process, carefully limits EA engagement with the Commission (Interview, EA official, 2007; House of Commons Environment Committee, 2006, p. 29). Thus at best only mild slippage (Proposition three) occurs. EA people only support EU Council negotiations and must adhere to the Ministerial/principal line (Interview, EA officials, 2007). The EA avoids letting its networking efforts compete with DEFRA's. The overall picture is the UK government maintaining a close rein on the EA's policy autonomy in both the domestic and EU context, in line with PA expectations.

\subsubsection{Climate Change Policy}

There has been some national debate about whether the EA had responsibility for UK climate change policy beyond flood control. The lack of a remit in the energy and transport sectors has always constrained EA CC scope. In the UK implementation of the EU's United Nations Framework obligations, the EA is responsible for implementing the EU Emissions Trading Scheme (ETS) and acts as a regulator for the sectoral climate change agreements and the voluntary Energy Efficiency Scheme.

Although not a leader in designing the ETS, the EA role as a regulatory and advisory body allowed it to influence UK government decisions, including a UK trading scheme that anticipated the EU's. The EA serves as the principal government advisor on such matters as climate capture and storage and as the regulator of key climate change emissions, including non-carbon dioxide emissions from plant installations and landfill sites (Interviews, EA officials, 2010).

There is less scope for the EA to model climate change given the presence of other UK institutes. The EA 
does have the scope to assess how the changing climate will evolve. A key EA strength has been its advanced integrated catchment strategy, providing rainfall and temperature data. The EA focus is less to deal with mitigation issues than with the monitoring and adaptation roles; the mitigation policy fights occur at the EU and UK ministerial levels. Both these implementation and knowledge-building tasks fit within the normal bounds of the PA relationship as the agency activities mesh with the preferences of the national and EU principals.

It is arguable that some policy slippage and reinterpretation has occurred in the question of CC policy adaption and the overarching contraction of the national budget. The EA adaptation role is fundamental: a central, and relatively protected, part of the EA budget is flood control. The New Labour Government pondered whether a standalone flood agency was more suitable for handling the future flooding challenge, but its review discarded this idea (Interview, two EA officials, 2007). The EA was particularly influential in pushing for CC adaptation into the UK Climate Change Bill agreed in 2007. Originally the proposal had focused on mitigation. Here both the EA, as well as DEFRA, worked to change the government legislation and policy preferences through reinterpretation and arguably social learning (Keskitalo, 2010).

However, the winter 2013-2014 floods placed the Agency's flood expertise and strategy in a political firestorm as many political (and government) actors blamed the EA for the Somerset flooding, rather than, for instance, the strategic government choices about how to spend a finite flood defence budget (Smith, 2014). This questioning of the EA's effectiveness has coincided with a wholesale workforce reduction (BBC News, 2014). The UK government and the EA have refuted claims that these cuts affect front-line flood prevention with climate change policy prioritised, but the reality is that the cuts have significantly reduced the EA's policy and science wings, many of which produce activities linked to climate mitigation and adaptation policy (Interview, EA official, 2007). This limits some of the wider UK and EU CC policy objectives.

The EA continues to promote its CC expertise at the EU level: for example, the EA convinced the Commission to accept the UK approach to flood risk management. The EA representatives managed to explain what the UK was doing and persuade the Commission to reinterpret its flood risk proposal to allow the EA to keep its system in place (Interview, EA officials, 2007, 2010). This section suggests that, as the budget crisis has become the UK government's focus, there has been some slippage between this prioritisation and some of the longer-term goals set for UK CC policy at the national and EU levels, but no greater policy autonomy as a result.

\section{Conclusions}

This conclusion examines first how the propositions of
Table 1 stand up to the evidence. Table 3 lays out the evidence uncovered in the case studies for each proposition. We then examine the wider analytical implications and pose questions for future research.

\subsection{Agency Findings}

Focusing first upon the strategic efforts to build policy autonomy, the general evolution of the EEA stands out as demonstrating the clearest sustained strategic effort, although this has not extended to the area of CC directly. Arguably the wider policy implications for this information-orientated agency are much smaller than the other two agencies with tremendous regulatory responsibilities and resources. Nevertheless, we see the EEA officials using the Regulation's textual ambiguities, and the multiple principals' differing preferences, to build a limited policy autonomy that did not exist originally in the preferences of at least one principal, the Commission. The Commission wished to protect its own policy powers and avoid duplicated effort. Of the three agencies, it is the EEA that has most successfully transformed and "educated" the outlook of the principals.

The EEA transformation of the principals' preferences indicates that several PA dynamics were involved (see Table 3). It is significant that the agency, in terms of the policy cycle, was providing information across the cycle, rather than dominating and defining a particular policy stage. More important was the existence of the multiple principals and the slippage that they created. Slippage was necessary but not sufficient: the EEA officials had to be willing to push the possibility of expanding the policy scope through a conscious strategy. They did so by learning (government learning and lesson drawing) to interpret/reinterpret their mandate, and by using their networks and other tasks to build strong relations with principals besides the Commission. This strategy had a multi-level dimension as it involved engagement with member state actors, such as the EA, but also other international organisations and non-EU countries.

In contrast, the EU member state agency (EA) case, despite involving multiple principals, does not reveal much evidence of efforts to overturn the preferences of core principals in either the overview or the climate change case study. The EA had a moderate level of success in using expertise to persuade the UK government and the Commission to rethink certain pieces of legislation. This reinterpretation was important in terms of the policy choices made, but did not carve out policy autonomy for the agency. This suggests the power of the UK executive with the ability of the majoritybacked government to radically alter the scope and shape of the agency in the face of the opinions of other principals. Other state agencies will need to be studied to generalise this conclusion. External events (the economic crisis) and the UK government's response have not extended but rather limited EA autonomy. 
Table 3. Evidence of policy autonomy mapped against the propositions.

\begin{tabular}{l} 
List of propositions \\
\hline Null hypothesis \\
(1) The default PA \\
proposition \\
\\
Propositions where PA \\
dynamics remain but are \\
made complicated
\end{tabular}

(2) Shirking

(3) Slippage

(4) Policy saliency

(5) Policy stage

(6) Exogenous dynamics

Propositions that transform PA dynamics

(7) Dualism

(8) Reinterpretation and learning

(9) Coalition-building

USEPA

In the climate change case study, most of the EPA policy outputs at $\mathrm{HQ}$ level conform to PA norms.

EPA regions shifted resources to CC under the SWDA.

Certain offices within the EPA continued to develop CC policy plans while waiting for the end of the Bush II

Administration.

The US Supreme Court ruling empowered the EPA to develop CC rules using the Clean Air Act against the Bush II White House wishes.

EPA regions in Northeast US re-interpreted the SWDA and work with state governors in low key fashion.

SWDA actions at regional level focused on implementation.

No evidence of this variable affecting PA relationships.

EPA regions shifting resources to $C C$ under the SWDA.

EPA regions shifting resources to $C C$ under the SWDA.

EPA regions built alliances with state governments on CC. Coalition building during effort to develop Mandatory Reporting of Greenhouse Gases Rule.

\section{EEA}

In the climate change case, the EEA outputs were focused on reports and information in line with PA norms.

No evidence presented.

The EEA's general policy scope has been enhanced by the explicit effort of certain principals (e.g. EP, Council) and the reviews of the EEA activities.

No evidence presented. EA

In the climate change case, most of the EA policy outputs conform to PA norms.

No evidence presented.

Marginal slippage might be possible given EU requirements but largely in line with Ministerial (PA) direction.

No evidence presented.

The focus on providing policy reports and providing information covers all stages.

No evidence of this variable affecting PA relationships.

No evidence provided.

No evidence provided.

Substantial reinterpretation of role to move beyond mere information provision.

Strong efforts made to reach out to the principals especially the EP and Council of Ministers, but also non-EU states, international organisations.
EA helped push government reinterpretation of 2007 CC Bill. EA succeeded in persuading Commission to accept UK flood risk approach.

No evidence provided. 
This lack of effort to promote autonomy does not mean that the EA operated without a strategy for engaging with the wider national and EU processes. It has had to learn and relearn its roles in the face of sustained government restructuring; it worked to build expertise and innovation in particular areas (government learning and lesson drawing). It received national and EU credit for expertise, building vital aspects that fed into the EU Water Framework Directive and rethinking of regulations. It has worked hard to engage other actors and to build a reputation for expertise. The agency does face issues of slippage (i.e., not meeting preferences of principals on particular issues) as it seeks to fulfil its main tasks with a much reduced work force, but there seems to be no scope at present to boost policy autonomy in CC or other areas.

The USEPA overview suggests that the Presidential executive and the US Congress have elaborated and developed control mechanisms, while also harnessing a range of interest groups and societal actors to monitor (and challenge) EPA decisions. The climate change history of the two most recent presidential administrations largely supports the null hypothesis affirming PA theory (see Table 3). In the Bush White House, the EPA policy offices tended to have preferences quite contrary to the White House leadership, but they had to bide their time with some low visibility shirking. There was policy and information development, but not outputs (as they would have been blocked). The Obama Administration has (cautiously) allowed the USEPA to pursue these preferences, but both face open hostility from elements of US society and Congress.

However, focusing on the subnational level and even slightly at the transnational level, we see EPA Regional officers exploiting relations to build alliances and to support (often Republican state government) initiatives that conflict with the White House preferences. The existence of other regulations requiring implementation allowed the Regional officers to reinterpret (government learning and lesson drawing) these requirements to include $\mathrm{CC}$ goals, creating a dualist scenario.

\subsection{Broader Themes}

Returning to the most different comparison, there does seem to be certain similar dynamics at work in the US and EU-level agency. Overall, the evidence for shirking, Proposition Two, is minimal for all three agencies, compared to cases of preference transformation and the continued assertion of the PA constraints. This broadly supports the null hypothesis and alerts us to the continuing importance of the PA dynamic.

Nevertheless, the multi-level governance and the multiple principals found in both systems indicate very strongly that there are important qualifications and conditions at work for the PA thesis. These conditions may not have dominated the three cases, but the epi- sodes of policy autonomy were significant, particularly for the EEA, and do not conform to the PA null hypothesis. The existence of the US Congress and European Parliament, as well as individual states with differing preferences, created conditions of slippage which both agencies exploited, and this involved some learning particularly for the EEA.

In terms of the comparison, the EA contrasts substantially with the other two agencies. With the relatively strong central control over the local areas in England and Wales and the dominance of a majoritybacked government executive, the scope for the EA to boost its policy autonomy against a highly centralised UK government was comparatively minimal.

The PA approach needs to delve more fully into the consequences of multiple actors and principals operating at different levels, creating political opportunities. Both the USEPA and the EEA were able to build alliances with sympathetic constituents to enhance policy autonomy. The possibilities of interactions beyond EU borders have also enhanced the EEA's position; the USEPA has been able to stretch its expertise and influence into relations with Canada and the EA. In acknowledging the importance of the PA dynamics, it remains important to embrace the critiques offered by the institutionalist and strategy arguments. Slippage did not simply result in policy autonomy. Both the USEPA and the EEA had to operate an active strategy of building coalitions of sympathetic allies (both principals and others) to underpin their efforts, including those efforts at reinterpretation. Indeed the cases suggest that (although this may not be necessary in cases of low visibility such as EPA regions implementing the SWDA) where there is potentially strong interest and resistance from one principal, it is vital to combine coalition-building with the strategies of dualism and reinterpretation.

At the same time, the institutionalist and strategy approaches, as articulated by Carpenter and Jacoby, need to pay closer attention to the PA dynamics. Transformation of the preferences of principals was possible, but it took on wider significance for both the USEPA and EEA when other principals and interested actors were active in the areas. Slippage of some kind has provided a vital condition for agency strategies to pursue policy autonomy. This also reinforces the understanding that lesson drawing and policy learning require favourable conditions for the ideas they generate to have a meaningful policy impact outside the agency's office.

This suggests a broader conclusion about the PA approaches and conditions: the instances where policy autonomy occurred tended to involve both PA situational conditions (propositions 2-6) and particular agency strategies (propositions 7-9). Agency reinterpretation happened where other favourable conditions occurred, such as slippage and low visibility policy im- 
plementation as well as coalition building.

Choosing a politically highly salient case such as climate change seems to have been significant, especially given the ability of regional EPA offices to make use of the SWDA. The pressure that the EA has found itself under concerning the recent floods, and the organised opposition across the US political spectrum, both reveal a policy environment where the larger national executive has been extremely watchful and interventionist. The EEA's move to greater policy autonomy did not occur in the climate change area. It is likely that other, less visible technical policy areas see greater scope for policy autonomy.

The evidence presented in this contribution, particularly with respect to the climate change case, strongly suggests that political executives (such as the White House and the UK ministries) are able to exert a substantial political control over the agencies and environmental policy administration. It takes a significant combination of multiple principals and interested parties, and an agency strategy, to generate real policy autonomy. Nevertheless, the importance of multiple actors and levels is notable in a number of transnational environmental policy areas, suggesting that there will be possibilities for strategic actors willing to push new understandings of policy (lesson drawing and policy learning) and build alliances (government learning).

\subsection{Future Research}

One interesting dynamic that needs further elaboration within the PA approach is the question of the impact of principals that also compete with the agent. The USEPA does not have a direct rival in governing environmental policy, but the case is very different for the two European agencies. Both DG Environment and DECC and DEFRA have been very reluctant concerning efforts of the respective agencies to expand policy autonomy. On one level, this has extended the control of the principal and limited policy autonomy; this supports the conclusion of Trondal (2011) who argues that duplication can increase principal's control. However, as Héritier and Lehmkuhl (2008) suggest, conditions of slippage may occur where other principals are willing to view the agency and the principal as rivals for policy advice; the EEA was able to exploit this to a degree.

In terms of the agencies being able to govern the climate change issue and other wicked problems, I offer three thoughts for further exploration. First, even compared to the USEPA, the EEA and EA have had relatively short histories; in that time, both agencies faced a continuing process of being reviewed with the potential for massive organisational restructuring. The USEPA has a more established and larger organisational approach that could wait for a new administration whilst still undertaking climate change policies. Second, political intervention seems to be inherent in such an issue as climate change, but this seems reasonable given the tremendous societal consequences of climate change; it cannot be left to technocracy. Finally, however, the necessity of dealing with such a complex issue suggests that an agency that can develop expertise on the problem and persuade the political masters to embrace this new understanding also is fundamental to successful governance.

\section{Acknowledgements}

The author thanks the Leverhulme Trust and the British Academy for their support of this research project, and thanks the 78 anonymized interview respondents for their input, and the editors and the four anonymous referees for their comments.

\section{Conflict of Interests}

The author declares no conflict of interests.

\section{References}

Bach, T., Niklasson, B., \& Painter, M. (2012). The role of agencies in policy-making. Policy and Sciences, 31(3), 183-193.

BBC News. (2014, February 14). UK floods: Environment Agency job cuts "on hold". Retrieved from http://www.bbc.co.uk/news/uk-politics-26187712

Bennett, C., \& Howlett, M. (1992). The lessons of learning: Reconciling theories of policy learning and policy change. Policy Sciences, 25(3), 275-294.

Busuioc, M., \& Groenleer, M. (2012). Wielders of supranational power? The administrative behaviour of the heads of European Union agencies. In $\mathrm{M}$. Busuioc, M. Groenleer, \& J. Trondal (Eds.), The agency phenomenon in the European Union: Emergence, institutionalisation and everyday decisionmaking (pp. 128-151). Manchester: Manchester University Press.

Calvert, R., McCubbins, M., \& Weingast, B. (1989). A theory of political control and agency discretion. American Journal of Political Science, 33(3), 588611.

Cappiello, D. (2009, February 17). AP interview: EPA near ruling on greenhouse gases. Retrieved from http://www.boston.com/news/nation/washington/ articles/2009/02/17/ap_interview_epa_near_ruling _on_greenhouse_gases?mode=PF

Carpenter, D. (2001). The forging of bureaucratic autonomy: Reputations, networks, and policy innovation in executive agencies, 1862-1928. Princeton: Princeton University.

Carrigan, C., \& Coglianese, C. (2011). The politics of regulation: From new institutionalism to new governance. Political Science, 14(1), 107-129.

Carrington, D. (2012, November 30). David Cameron 
forced into U-turn on flood defence spending cuts. The Guardian. Retrieved from http://www.the guardian.com/environment/2012/nov/30/flooding$120 \mathrm{~m}$-defence-spending

Coen, D., \& Thatcher, M. (2008). Network governance and multi-level delegation: European networks of regulatory agencies. Journal of Public Policy, 28(1), 49-71.

Commission of the EC. (1989). Proposal for a Council Regulation (EECP) on the establishment of the European Environment Agency and the European Environment Monitoring Information Network (COM (89 303 Final)).

Commission of the EC. (2003). Report from the Commission to the Council: Review of the European Environment Agency (COM (2003 800 Final, 22/12)).

Conceição-Heldt, E. da (2013). Do agents "run amok"? A comparison of agency slack in the EU and US trade policy in the Doha Round. Journal of Comparative Policy Analysis: Research and Practice, 15(1), 21-36.

Cook, J., \& Rinfret, S. (2013). A revised look: EPA rulemaking processes. Journal of Environmental Studies and Science, 3(3), 279-289.

Council of the EC. (1990). Council Regulation (EEC) No. 1210/90 of 7 May 1990 on the establishment of the European Environment Agency and the European Environment Information and Observation Network. Official Journal of the European Communities L 120, 11/05, 1-6.

Council of the EC. (1999). Council Regulation (EEC) No. 933/1999 of 29 April 1999 Amending Regulation (EEC) No. 1210/90. Official Journal of the European Communities L 117, 05/05, 1-4.

Council of the EC (2003). Council Regulation (EC) No. 1641/2003 of 22 July 2003 Amending Regulation (EEC) No. 1210/90. Official Journal of the European Communities L 245, 29/09, 1-3.

DEFRA. (2003). Review of legislation affecting integration within the Environment Agency: Final report. London: DEFRA.

DEFRA. (2012a). Environment protected and business boosted by cutting unnecessary red tape. Retrieved from http://www.defra.gov.uk/news/2012/03/19/ red-tape-challenge/

DEFRA. (2012b). Triennial Review of the Environment Agency and Natural England. Retrieved from www.defra.gov.uk

DEFRA. (2013). Triennial Review of the Environment Agency and Natural England. Retrieved from https://www.gov.uk/government/publications/trie nnial-review-of-the-environment-agency-ea-andnatural-england-ne

EEA. (n.d.). EIONET fact sheet. Copenhagen: EEA.

EEA. (2007). Climate change and water adaptation issues (Technical report 2/2007). Copenhagen, EEA.

EEA. (2009). EEA strategy 2009-2013: Multi-annual
Work Programme. Copenhagen, EEA.

EEA. (2015). National emissions reported to the UNFCCC and to the EU Greenhouse Gas Monitoring Mechanism. EEA Website. Retrieved from http:// www.eea.europa.eu/data-and-maps/data/nationalemissions-reported-to-the-unfccc-and-to-the-eugreenhouse-gas-monitoring-mechanism-7

ENDS Report. (2010, October). Change your culture, DEFRA tells agency. Retrieved from http://www. endsreport.com $/ 25553$

Groenleer, M. (2009). The autonomy of European Union agencies: A comparative study of institutional development. Delft: Eburon.

Hawkins, D., \& Jacoby, W. (2006). How agents matter. In D. Hawkins, D. Lake, D. Nielson, \& M. Tierney (Eds.), Delegation and agency in international organizations (pp. 199-228). Cambridge: Cambridge University Press.

Hawkins, D., Lake, D., Nielson, D., \& Tierney, M. (2006). Delegation under anarchy: States, international organizations, and principal-agent theory. In D. Hawkins, D. Lake, D. Nielson, \& M. Tierney (Eds.), Delegation and agency in international organizations (pp. 3-38). Cambridge: Cambridge University Press.

Heinzerling, L. (2012). Introduction: Climate change at EPA. Florida Law Review, 64(1), 1-13.

Héritier, A., \& Lehmkuhl, D. (2008). Introduction: The shadow of hierarchy and new modes of governance. Journal of Public Policy, 28(1), 1-17.

Hoornbeek, J. (2000). Information and environmental policy: A tale of two agencies. Journal of Comparative Policy Analysis: Research and Practice, 2(2), 145-187.

House of Commons Environment, Food and Rural Affairs Committee. (2006). The Environment Agency (Seventh report of the session 2005-2006, HC 7801). London: Stationery Office.

IEEP, \& EIPA. (2003). Evaluation of the European Environment Agency: An IEEP/EIPA study. A Final report to $D G$ environment. Brussels and Maastricht: IEEP and EIPA.

Keskitalo, E. (2010). Climate change adaptation in the United Kingdom: England and South-East England. In E. Keskitalo (Ed.), Developing adaptation policy and practice in Europe: Multi-level governance of climate change (pp. 97-147). Dordrecht: Springer.

Koop, C. (2011). Explaining the accountability of independent agencies: The importance of political salience. Journal of Public Policy, 31(2), 209-234.

Ladeur, K. (1996). The new European agencies: The European Environment Agency and prospects for a European Network of Environmental Administrations (EUI Working Paper RSC 96/50). Florence: EUI.

Landy, M., Roberts, M., \& Thomas, S. (1994). The Environmental Protection Agency: Asking the wrong questions from Nixon to Clinton. Oxford: Oxford University Press. 
Lazarus, R. (2004). The making of environmental law. Chicago: University of Chicago Press.

Lee, J. (2012). The administrative broker: Bureaucratic politics in the era of prevalent information. The American Review of Public Administration, 43(6), 690-708.

MacDonald, J. (2013). Congressional power over executive branch policy making: Limitations on bureaucratic regulations, 1989-2009. Presidential Studies Quarterly, 43(3), 523-537.

Majone, G. (1997, July 21-25). The European Environmental Agency and the politics of structural choice. Lecture given at the Summer Symposium on the Innovation of Environmental Policy, University of Bologna.

Massachusetts et al. v. Environmental Protection Agency et al. 2007 No. 05-1120 (USA).

McCubbins, M., Noll, R., \& Weingast, B. (1987). Administrative procedures as instruments of political control. Journal of Law, Economics, and Organization, 3(2), 243-277.

McGarity, T. (2013). EPA at Helm's Deep: Surviving the fourth attack on environmental law. Fordham Environmental Law Review, 24, 205-241.

McMahon, R. (2006). The Environmental Protection Agency: Structuring motivation in a green bureaucracy. Brighton: Sussex Academic Press.

Opp, S. (2011). Bureaucratic discretion and political control of the Resource Conservation Recovery Act (RCRA). International Journal of Public Administration, 34(12), 753-763.

Recovery.gov. (2009, May 15). Agency Recovery Plan: Environment Protection Agency. Retrieved from http://www.recovery.gov/?q=content\%2Fagencyrecovery-plan\&agency_id-020

Reichert, M.S., \& Jungblut, B. (2007). European Union external trade policy: Multilevel principal-agent relationships. Policy Studies Journal, 35(3), 395-418.

RGGI (2009). Regional Greenhouse Gas Initiative: An initiative of the Northeast and Mid-Atlantic States of the US. Website. Retrieved from http://rggi.org/ about/history

Smith, C. (2014, February 2). Difficult choices as flood waters rise. The Telegraph. Retrieved from http:// www.telegraph.co.uk/earth/environment/1061362 7/Difficult-choices-as-the-flood-waters-rise.html

Tallberg, J. (2002). Delegation to supranational institutions: Why, how and with what consequences? West European Politics, 25(1), 23-46.

Thatcher, M., \& Stone Sweet, A. (2002). Theory and practice of delegation to non-majoritarian institutions. West European Politics, 25(1), 1-22.

Trondal, J. (2010). An emergent European executive order. Oxford: Oxford University Press

Trondal, J. (2011). Domestic agencies in an emergent European executive order. Journal of European Integration, 33(1), 55-74.

USEPA. (2003). 2003-2008 EPA strategic plan: Direction for the future. Washington DC: USEPA.

USEPA. (2008). Advance Notice of Proposed Rulemaking: Regulating Greenhouse Gas Emissions under the Clean Air Act. EPA. Retrieved from http//www. epa.gov/climatechange/anpr.html

USEPA. (2009). Proposed endangerment and cause or contribute findings for greenhouse gases under the Clean Air Act. EPA. Retrieved from http//www. epa.gov/climatechange/endangerment.html

USEPA. (2012). Climate change regulatory initiatives. $E P A$. Retrieved from http://www.epa.gov/climate change/EPAactivities/regulatory-initiatives.html

Volcovici, V. (2014, May 20). EPA carbon curbs to reach beyond power plant "fence", aiding cap-and-trade. Reuters. Retrieved from http://www.reuters.com/ assets/print?aid=USL1N0050CD20140520

Waterman, R., Rouse, A., \& Wright, R. (2004). Bureaucrats, politics, and the environment. Pittsburgh: University of Pittsburgh.

Zito, A. (2009). European agencies as agents of governance and EU learning. Journal of European Public Policy, 16(8), 1224-1243.

\section{About the Author}

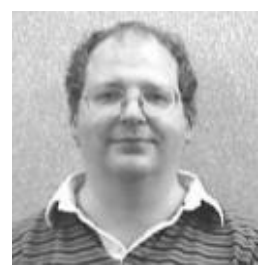

Dr. Anthony R. Zito

Professor Anthony R. Zito is Professor of European Public Policy at Newcastle University. Dr. Zito is currently Co-Director of the Jean Monnet Centre at Newcastle University and Co-Editor of the journal Environmental Politics. He has authored Creating environmental policy in the European Union and numerous journal articles on the European Union policy process and environmental actors and policy-making; he has recently co-authored Environmental Governance in Europe (2013). 